\title{
Bio-Fertilizer, ground magnesium limestone and basalt applications may improve chemical properties of Malaysian acid sulfate soils and rice growth
}

\begin{abstract}
Acid sulfate soils are normally not suitable for crop production unless they are appropriately ameliorated. An experiment was conducted in a glasshouse to enhance the growth of rice, variety MR219, planted on an acid sulfate soil using various soil amendments. The soil was collected from Semerak, Kelantan, Malaysia. Ground magnesium limestone (GML), biofertilizer, and basalt (each $4 \mathrm{t}$ ha-1) were added either alone or in combinations into the soil in pots $15 \mathrm{~d}$ before transplanting. Nitrogen, $\mathrm{P}$ and potash were applied at 150,30, and $60 \mathrm{~kg}$ ha-1, respectively. Three seven-day-old rice seedlings were transplanted into each pot. The soil had a $\mathrm{pH}$ of 3.8 and contained organic $\mathrm{C}$ of $21 \mathrm{~g} \mathrm{~kg}-1, \mathrm{~N}$ of $1.2 \mathrm{~g} \mathrm{~kg}-1$, available $\mathrm{P}$ of $192 \mathrm{mg} \mathrm{kg}-1$, exchangeable $\mathrm{K}$ of $0.05 \mathrm{cmolc} \mathrm{kg}-1$, and exchangeable $\mathrm{Al}$ of $4.30 \mathrm{cmolc} \mathrm{kg}-1$, with low amounts of exchangeable $\mathrm{Ca}$ and $\mathrm{Mg}(0.60$ and 0.70 cmolc $\mathrm{kg}-1)$. Bio-fertilizer treatment in combination with GML resulted in the highest $\mathrm{pH}$ of 5.4. The presence of high $\mathrm{Al}$ or Fe concentrations in the control soil without amendment severely affected the growth of rice. At $60 \mathrm{~d}$ of growth, higher plant heights, tiller numbers and leaf chlorophyll contents were obtained when the bio-fertilizer was applied individually or in combination with GML compared to the control. The presence of beneficial bacteria in bio-fertilizer might produce phytohormones and organic acids that could enhance plant growth and subsequently increase nutrient uptake by rice. Hence, it can be concluded that addition of bio-fertilizer and GML improved rice growth by increasing soil $\mathrm{pH}$ which consequently eliminated $\mathrm{Al}$ and/or $\mathrm{Fe}$ toxicity prevalent in the acid sulfate soil.
\end{abstract}

Keyword: Al toxicity; Amendments; Beneficial bacteria; Fe toxicity; Indoleacetic acid; Organic acids 